\title{
Job Burnout of English Teachers in Colleges and Universities and Its Countermeasures
}

\author{
Wang Lei \\ Foreign Language Department \\ Jilin Business and Technology College \\ Changchun, China \\ 182076127@qq.com
}

\begin{abstract}
Job Burnout” has attracted extensive attention since it is put forward. The teacher group is at high risk of "job burnout". "Job burnout" is a recessive occupational injury with enormous negative impact which may exert a tremendous adverse impact on individual physical and psychological health, work efficiency and effect. For the teachers who cultivate talents, the influence of "job burnout" is even bigger. The teaching quality may be influenced and the development of students may also be influenced with immeasurable negative effects on society. In this thesis, the reasons for the job burnout of English teachers in colleges and universities and its countermeasures are analyzed.
\end{abstract}

Keywords-Colleges and Universities; English Teachers; Job Burnout; Own Qualities; Reward Mechanism

\section{INTRODUCTION}

Facing students of different levels, the English teachers in colleges and universities may face the pressures of few course hours and heavy tasks. On the one hand, the teachers should enhance teaching efficiency, guarantee the promotion of students' English level and face the pressures of research tasks and knowledge aging; hence, the English teachers in colleges and universities may be under "job burnout", unable to work regularly and lose confidence in teaching. In this thesis, the concrete content of job burnout of English teachers in colleges and universities and its countermeasures will be discussed. It is hoped that the job burnout of English teachers in colleges and universities may be improved and the teachers can take an active part in the English teaching activities. [1]

\section{CONCRETE CONTENT OF JOB BURNOUT OF ENGLISH TEACHERS IN COLLEGES AND UNIVERSITIES}

\section{A. Connotation of Teachers' Job Burnout}

Job burnout, put forward by Freudenberger, refers to the mental and physical fatigue and exhaustion of the individual under work stress. He thinks that job burnout is a kind of emotional exhaustion symptom that is easy to appear in the helping profession. Job burnout mainly includes emotional exhaustion, powerlessness or diminished personal accomplishment and depersonalization. The following describes the concrete manifestation of job burnout of English teachers in colleges and universities. [2]
Firstly, due to the heavy teaching task and high teaching pressure, the English teachers in colleges and universities are easy to lose work enthusiasm. They may feel tired on the emotional level, finally leading to the appearance of emotional exhaustion. Secondly, the teaching objects of English teachers in colleges and universities are composed of students of different levels and the university English is a vitally important basic subject and thus the teachers should be responsible for enhancing the students' English level so as to lay a good foundation for their future. However, there are many problems and difficulties in the university English teaching process and the teachers fail to obtain remarkable effects in English teaching, causing powerlessness of English teachers. In addition, the career development space of English teachers in colleges and universities is restricted and thus sense of personal achievement can't be achieved. Consequently, the English teaching becomes a boring work that leads to the teachers' failure of exerting talents. Finally, the negative effects lead to the physical and mental fatigue of English teachers in colleges and universities so that their work enthusiasm reduces greatly and they begin to treat work negatively, thus reducing work efficiency.

\section{B. Concrete Reasons for Job Burnout of English Teachers in Universities}

1) Complex and Versatile Teaching Objects of University English

Firstly, different from primary schools and middle schools, the colleges and universities absorb students from all parts of the country. On the one hand, there are cultural differences across the country; one the other hand, the economic development level, the educational level and the requirements on students' English competence are different, which leads to the unevenness of students' English level, embodied by oral ability difference, listening competence difference and writing and application ability difference, bringing obsessions to university English teaching. Secondly, different from senior high schools, the university teaching should lay emphasis on expertise. Therefore, the requirements on English by different majors and the requirements on English ability in different professional fields are different. Finally, due to the distinctions among majors, the male female ratio in each class is different and even may vary greatly. The learning attitudes and abilities of male and female students are greatly different, bringing difficulties to English teaching. Due to the different teaching 
objects, the English teachers should formulate different teaching programs and adopt different teaching methods on the basis of different objects. Moreover, the teaching programs and teaching methods should be scientific and reasonable as well as correspond to reality, aggravating the working load and teaching pressure of teachers, which causes professional burnout. [3]

\section{2) Particularity of University English Course Content}

As a language subject with rich course contents, the university English should help students master the basic grammar, require the students to accumulate vocabularies, sentences and language chunks and train the students the comprehensive abilities of listening, speaking, reading and writing. However, the class hours of university English are limited and thus it is difficult to complete the high-standard and demanding teaching activities within the limited class hours. Moreover, the university English course reform raises higher demands on university English teaching. With the increasingly heavy teaching pressure, the English teachers in colleges and universities are exhausted emotionally, leading to the professional burnout.

\section{3) Special Status of University English in University} Teaching

As an international language, English is important during each teaching phase. The English teaching is more important during the undergraduate phase, the transitory stage from school to society. Moreover, along with information globalization and economic globalization, college English test band $4 / 6$ is a rigid standard for the recruitment in many enterprises, which invisibly puts forward higher requirements on university English teaching. Facing more and more challenges and keeping balance between English ability and test-taking ability, the English teachers feel powerless. As time passes, the English teachers in colleges and universities face greater mental stress and their physical and psychological health is affected strongly, and thus the feeling of job burnout appears.[4]

\section{4) Development Prospect Limitations for English} Teachers in Colleges and Universities

The students begin to relax in studying after entering into university, however, English requires students to accumulate vocabulary and recite; hence, fewer students learn actively with learning interest. The college English teachers should endeavor to enhance the learning initiative. In addition, there are many problems in university English teaching and teaching activities and thus the normal teaching results can't be achieved. Under such circumstance, the English teachers in colleges and universities begin to lose self-confidence and sense of achievement, reducing their enthusiasm for work. Since the teaching results are always unsatisfactory, English teachers in colleges and universities have no advantages in teaching assessment and professional evaluation and their development prospect is restricted. Under the pressures, the sense of professional belonging of English teachers in colleges and universities can't be achieved, their sense of achievement can't be satisfied and their development prospect is restricted; hence, the English teachers in colleges and universities are facing enormous pressure, which may lead to the feeling of job burnout.

\section{COUNTERMEASURES FOR JOB BURNOUT OF ENGLISH TEACHERS IN COLLEGES AND UNIVERSITIES}

\section{A. Countermeasures at Individual Level}

1) Enriching Knowledge Reserve and Improving Qualities

Due to the major setup in colleges and universities, most of the English teachers in colleges and universities are facing nonEnglish major students who lack of depth in learning and academic research and pay more attention to daily communication. Due to the current education system, the university English fails to achieve the purpose of learning in order to practice and is used to cope with College English Test. If things continue this way, the teachers' knowledge reserve deficient owing to the teaching limitation and retarded knowledge growth. Along with the acceleration of social information process and knowledge update, this will be increasingly severe and finally the teachers in colleges and universities will be tired to cope with the work, leading to professional burnout; hence, it is necessary to enrich the knowledge reserve. The English teachers in colleges and universities can continually acquire new knowledge and master top information through short-term overseas studies and regular academic exchanges. In addition, upgrading the qualification is also a good method for improving themselves, which may let the teachers in colleges and universities be students as well as teachers, making for the teaching work. The teachers in colleges and universities can enhance their own qualities, change professional attitudes and maintain feeling of freshness while enriching them so that they can cope with the difficulties during their career as well as the job burnout due to the failure to obtain sense of achievement.

2) Changing Teaching Methods and Building New Teacher-student Relationship

Owing to the difference between middle schools and colleges, the college teachers will not contact with the students as middle school teachers and even the students do not know the names of the classroom teachers. The inculcation education is applied in many classrooms and thus the teachers are lack of interaction with students who need to accept knowledge passively. [5] The classroom atmosphere tends to be oppressive and the teachers are lack of passion, leading to the job burnout of English teachers. Hence, the existing teaching method should be changed from the traditional model of teaching and studying to the model of learning while teaching; the inculcation classroom should be changed from teacher guiding to investigation classroom teaching with students' divergent thinking, which may increase the communication between students and teachers and enhance teaching quality. Meanwhile, such new teaching method has higher requirements on teacher's knowledge reserve, comprehensive ability, rhythm controlling ability and comprehensive quality, making the teaching become challenging and interesting; the teachers' pressure for preparing lessons can be alleviated through delivering the classroom initiative to students. 


\section{B. Countermeasures at Collective Level}

1) Changing Evaluation Methods for English Teachers in Colleges and Universities

Along with the promotion of economic globalization, the colleges and universities begin to pay more attention to English teaching, accompanying by the emphasis on the pass rate and excellent rate of College English Test. College English Test is not only a test on the English level of students in colleges and universities, but also on the teaching quality of English teachers in colleges and universities. However, the university English is different from middle school English which lays particular stress on introduction with the purpose to make the students have a preliminary understanding of English. The middle school English is confined to textbooks and the English teachers can obtain sense of achievement through testing scores and enrollment rates of college entrance examinations and senior high school entrance examinations. However, the English teaching objectives change. Compared with English in textbooks, the college English lays particular stress on practical application; moreover, the English teachers in colleges and universities can't obtain sense of achievement through the results of College English Test. In addition, the English teachers in colleges and universities are evaluated in the aspects of scientific payoffs, theses and student grading besides teaching quality; with the solidified system, the evaluation method lacks of flexibility, restraining the development space of teachers. In the meantime, the teachers face heavy course loads apart from research tasks owing to the particularity of college particularity; therefore, when evaluating the English teachers in colleges and universities, the people oriented principle should be applied with emphasis on the personal development of teachers and the teaching and scientific research should be evaluated separately; the evaluation on teachers should be divided into two based on the conditions and career expectations to keep balance between efforts and rewards so as to make the teachers obtain sense of achievement and avoid job burnout.[6]

2) Establishing Reward Mechanisms for Teachers in Colleges and Universities

The colleges should set up the reward mechanism for English teachers apart from enhancing self-qualities. Owing to the particularity of college English, the repeated job contents, family and future development, the English teachers in colleges and universities bear more pressure than teachers of other subjects, but there are reward mechanisms for them. The longterm and heavy course loads will dribble away their enthusiasm for work and the non-equivalence between efforts and rewards will lead to the loss of confidence in work so that the teachers will drift along with burnout. In order to change the current situation, it is necessary to change the teachers' mentality and meanwhile it is not allowed to neglect the colleges. The colleges and universities should pay close attention to the future career development of teachers; organize academic communications regularly to offer teachers with a favorable environment for promoting their level. For the teachers achieving bigger results in teaching or scientific research, the reward mechanism should be applied to increase their working enthusiasm. In addition, the colleges can organize the English teachers to study abroad at public expense during the winter and summer vacations to experience overseas teaching ideas, improve deficiencies and make progress.

\section{3) Implementing English Course Reform in Colleges and} Universities

At present, most of domestic colleges and universities apply the principle of one teacher for English of one class and one teacher with several classes. A teacher should be responsible for training the listening, speaking, reading, writing and translating ability of all the students in one or several classes. There are twenty to forty people in one class in the colleges and universities, which is an enormous workload. As a college teacher, teaching is not the only task; moreover, the scientific research also requires efforts, leading to the tremendous mental stress of teachers in colleges and universities; therefore, it is imperative for the course reform in colleges and universities. [7]Due to the professional diversity, the pertinence of general English courses should be strengthened according to the specialties, such as business English, daily English and accounting English. Interesting English classes can also be set up according to the students' interests. In the meantime, listening, speaking, reading and writing can also be taught separately by different English teachers to reduce the heavy burdens of English teachers. The traditional one-to-many teaching method is boring without challenges and may reduce the teaching enthusiasm; hence, the new many-to-many teaching method can be applied and one class should be taken as a unit; the mixed class can also be applied in English teaching and the students should be divided into classes according to the selected courses so as to increase the enjoyment of English courses.

\section{CONCLUSIONS}

The job burnout may make the English teachers lose enthusiasm in work and reduce teaching quality, thus exerting an influence on English study and the whole educational business. In order to avoid the enormous influence of job burnout, the English teachers in colleges and universities should adjust mental attitudes, respond actively to the job, change teaching methods and build amicable interaction with students; moreover, the colleges and universities should strive to consider for English teachers, change the inherent and laggard teacher evaluation system, establish reasonable teacher evaluation system and reward mechanism on the basis of English teachers and implement university English education reform so as to pave the way for the career planning of English teachers in colleges and universities and restore their confidence on career.

\section{REFERENCES}

[1] Ning Xin. On Job Burnout of English Teachers in Colleges and Universities[J]. Journal of Changsha Railway University (Social Sciences), 2013,14(1):165-166.

[2] Han Tao. Job Burnout of English Teachers in Universities and Its Countermeasures [J]. New Curriculum Research (Middle ThirdDouble),2013, (6):52-53,56. 
[3] Fan Lin, Yang Jieying. Job Burnout of English Teachers in Colleges and Universities and Its Countermeasures-based the Career Development of Teachers[J] Foreign Language Teaching.2015 (03)

[4] Yang Hong. The Pressure of Teachers from the College English Teaching Reform [J] Scientic and Technology 2016.02.

[5] Lv Qinfg bin. On Romoving the Job Burnout of Teachers [JJournal of China Education 2013 (06).
[6] Ma Yun. The Improvement of Objective of Major Development during the period of "Job Burnout" [J] Journal of Education. 2011(09)

[7] Wang Xiaoying, Li He. The Investigation of Current Situation of Three Colleges on "job Burnout" of Teachers[J] . Education and Career. 2007 (29) 